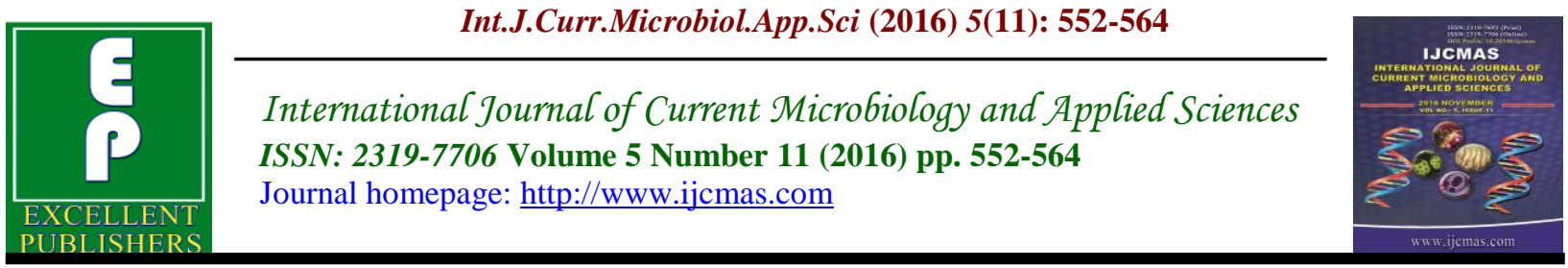

Original Research Article

http://dx.doi.org/10.20546/ijcmas.2016.511.066

\title{
Impact of Cocklebur (Xanthium indicum) Allelochemicals on Vegetative Growth Parameters of Green Gram (Phaseolus radiatus L.)
}

\author{
S.P. Adhikary ${ }^{*}$ and S.N. Sabat ${ }^{2}$ \\ ${ }^{1}$ Department of Botany, Aska Science College, Aska-761111, Dist. Ganjam, Odisha, India \\ ${ }^{2}$ Department of Botany, N.B.C. College, Kendupadar, Dist. Ganjam, Odisha, India \\ *Corresponding author
}

\begin{abstract}
A B S T R A C T
Keywords

Allelopathy, Agricultural crop,

Phaseolus radiatus, Vegetative growth, Dust.

\section{Article Info}

Accepted:

24 October 2016

Available Online:

10 November 2016

Pot culture and field experiment were conducted to evaluate the allelopathic effect of different concentrations of various types of dust of Xanthium indicum L. on the vegetative growth parameters such as - development of total number of leaves per plant, height of the plant, total leaf area and leaf area index of green gram (Phaseolus radiatus). The results showed that different concentrations of various types of dust of test weed $(5,10,15$ and $20 \%)$ in pot were influenced significant and caused inhibitory effect on vegetative growth parameters crop. In case of field experiment ratio of crop plant (C.P.) \& Xanthium plant (X.P.) per plot (100:00, $75: 25,50: 50$ and 75:25) were exhibited negative correlation between increase of test weed population in experimental plot and vegetative growth parameters of the crop. The study indicates that the allelochemicals released from the various types of dust into the soil in pot culture experiment and increased weed density of the field were suppressed the above parameters of the of the green gram plant.
\end{abstract}

\section{Introduction}

Allelopathy is a sub-discipline of chemical ecology that is concerned with the effects of chemicals produced by plants or microorganisms on the growth, development and distribution of other plants. Allelopathy plays an important role in agricultural ecosystems and in a large scale, in the plant covers among the crop-crop, crop-weed and tree-crop. The term "allelopathy" signifies the interactions between plants which might lead to either stimulation or inhibition of growth. Struggle for space and nutrients for propagation, continuity and survival is the most powerful law of the nature. Different groups of plants like; algae, lichens, crops and annuals and perennial weeds have wide known allelopathic interactions (Ahmad et al., 2004; Uddin et al., 2007). Allelochemicals belong to different categories of secondary compounds such as phenols, benzoic and cinamic acids derivates, flavonoids, tannins, coumarines, terpenoids, alkaloids and polyaccetylenes (Duke et al., 2000). These chemical compounds with allelopathic activity are regulated by environmental factors such as water potential of the environment, temperature, soil moisture, light intensity, nutrients, soil microorganisms and perhaps other factors. They are distributed in varying 
concentrations in different organs of plants including leaves, stem and roots (Inderjit, 1996; Chon et al., 2002). Day et al., (2003) reported that allelochemicals as nonnutritional chemicals produced by one organism which affect germination growth, health and behavior/population biology of other crops. Allelochemical compounds inhibited plant growth by effecting physiological processes among them, the effect on ion transport across membrane and hydraulic conductivity are highly important since the root is the first plant structure to come into contact with allelochemicalc in the rhizosphere (Blum et al., 1999). Rhizosphere allelochemicals, may be strongly affected the root tip as a result the rate of growth of crop plants are reduced. Chon et. al., (2002) reported that some plant genotypes are likely to escape the allelochemical(s) by being "hypersensitive". The effects of these compounds are often observed to occur early in the life cycle causing inhibition and modification of plant growth and development (Ahmed et al., 2007). Shajie and Saffari (2007) reported that leaves and stems extracts of Hordeum vulgare L. significantly reduced germination and seedling growth in corn (Zea mays L.), canola (Brassica napus L.), sesame (Sesamum indicum L.), corn (Zea mays L.) weeds Lentil (Lens culinaris Medic) and chickpea (Cicer arietinum L.). These allelochemicals also affected corn seedlings either by decaying of hypocotyls or by producing of dwarf plants. Saffari and Torabi-Sirchi (2011) reported that wheat straw extract (variety of Falat) had a significant effect on reducing radicle length growth on corn 647 variety at concentration of 20,40, 60, 80 and $100 \%$. Tanveer et al., (2008) observed that mean germination time in maize (Zea mays L.), barley $(\mathrm{H}$. vulgare L.), rice (Oryza sativa L.), wheat (T. vulgare L.) and sunflower was reduced by leaf leaches of Hordeum vulgare L. The increase in malondialdehyde synthesis is a common response of plants to allelochemicals, and this might be a subsequent response of plant to these chemicals beside cellular damage. Allelochemicals adversely affect malondialdehyde biosynthesis and accumulation by interfering in malondialdehyde biosynthesis and/or destruction. The upcoming negative effects of these processes would be retarding of photosynthesis and poor plant growth (Dash et al., 2013). Whenever two or more plants occupy the same niche in nature they compete with each other for various life support requirements (Chon et al., 2005). Higher plants (tree crops) release some phytotoxins into soil which adversely affect the germination and yield of crops (Kaletha et al., 1996; Kumar et al., 2006). Allelochemicals enter through the plant cell membrane and change the activity and function of certain enzymes (Li et al., 2010).

Green gram belongs to the family Leguminosae having unusual flower structure, podded fruits, and the ability to form nodules with rhizobia. In the context of human importance, it is with grain legumes contributing $33 \%$ of the dietary protein nitrogen $(\mathrm{N})$ for humans need. Legume seeds contain 20\% - 50\% protein which is highly essential for balanced diet. Green gram is generally catch crop in between cereals to enhance crop yield by increasing soil nitrogen through root nodules of rizhobia.

Cocklebur (Xanthium indicum L) is a weed, which is predominant in post harvested paddy field of study area where farmers of this locality cultivated green gram crop during winter season. Putman and DeFrank (1983), Duzenli et al., (1993) and Kadioglu (1997) reported that cocklebur causes damage on the crops (cotton, onion, sunflower and some vegetables) mostly 
during summer. Data are needed to know whether cocklebur has any negative allelopathic effect on the crops besides its competition. There are several reports mentioned on allelochemicals from different plants and test plant that negatively affect crops but there is very no information about the effects of Xanthium indicum allelochemicals on the vegetative growth parameters such as - development of total number of leaves per plant, height of the plant, total leaf area and leaf area index of green gram. Basing on the above facts and review literatures, the main objective of this study was to evaluate the effect of different concentration of various types of dust of Xanthium indicum on the vegetative growth parameters such as - development of total number of leaves per plant, height of the plant, total leaf area and leaf area index of green gram (Phaseolus radiatus) of green gram (Phaseolus radiatus L.).

\section{Materials and Methods}

In the morning hours Xanthium indicum plants collected at flowering and post flowering stage, from agricultural fields, were washed thoroughly with tap water followed by distilled water to remove the dust and other adhering particles from the surface of plants. Plant parts such as leaves, fruits were separated and allowed to dry-up in an incubator at $40 \pm 2^{0} \mathrm{C}$. Different types of dust from leaves, fruits and whole plant body were prepared as per the methods described below.

\section{Pot-culture experiment}

These experiments were conducted in the open field $\left(19^{0}-80 \mathrm{~N}\right.$ and $\left.84^{0}-30 \mathrm{E}\right)$ in the departmental garden of Aska Science College, Aska of Ganjam district. Earthen pots were of $25 \times 25 \mathrm{~cm}$ size containing equal quantity of well mixed sandy soil and cow-dung manure in a ratio of $8: 1$ parts (w/w) were taken. In order to have 5, 10, 15 and $20 \%$ concentration of whole-plant , leaves and fruits dusts separately in the soil of the pots, 5, 10, 15 and 20 grams of different dust were added per 100 grams of soil manure mixture in pots separately prior to sowing the seed. The visually selected and surface sterilized seeds of each test cultivar were directly sown @10 seed per pot. The pots were divided into 5 sets with 7 pots in each set. Out of 5 sets, one set was maintained without dust which served as control for individual crops. Care was taken to add equal volume of water in each pot periodically during the growth period of crops. After 10 days of germination the seedlings were thinned to stand 4 healthy seedlings per pot which were allowed to grow in pots till harvest.

\section{Field study experiments}

For field experiments, 3 plots measuring 200 sq. m. $(20 \times 10 \mathrm{~cm})$ were chosen near Aska Science College campus $\left(19^{0}-80 \mathrm{~N}\right.$ and $84^{0}$ - 30E) departmental garden, Aska. The plots were well ploughed twice after harvesting of rice crop and uniformly mixed with cowdung manure. The surface sterilized seeds of green gram were sown uniformly in the board casting method in respective fields. Then each field was divided into 20 plots having an area of 10 sq. m. $(2 \times 5 \mathrm{~m})$ each. The crop plants and Xanthium weeds were allowed to grow in field under natural condition. Out of 20 plots of each field, 2 plots were ear-marked for control and rest 18 plots were ear-marked for 3 types of experiments. Fifteen days after sowing (DAS) in control plots (1-2), all the Xanthium weeds were weeded out and only 20 healthy crop plants were allowed to grow, in plot No. 3-8, the plants were thinned to 15 per plot and Xanthium weeds were allowed to grow 5 plants per plot, in 
plot No. 9-14, the crop plants were thinned to 10 per plot and Xanthium weeds were allowed to grow 10 plants per plot, in plot No. 15-20, the crop plant and Xanthium weed ratio was maintained in a ratio of 5:15 per plot for test crop. The plots were randomly designed basing on the population of test weed plants. All other plants were weeded out from the plots. In all slots of plants were allowed to grow in the field till harvest under natural conditions. Care was taken for prevention of pests.

\section{Vegetative Growth parameters}

The vegetative growth parameters of pot cultured and field-grown plants such as (a) development of total number of green leaflets per plants (b) height of the plant (c) total leaf area per plant and (d) leaf area index (LAI) were recorded at an interval of one week from 20 days after sowing till flowering.

\section{Number of leaf-let developed per plant}

The number of fully developed green leaflets per plant was counted and recorded during the vegetative growth period as stated above.

\section{The height of the test crop plant}

The height of the test crop plants of control and treated pots as well as plots were measured with the help of a meter scale from the soil surface to the tip of the plant and recorded as per the experimental scheduled.

\section{Leaf area}

The area of the leaf-lets were measured by taking the outlines of individual leaf-lets of both control and treated plants grown in pot condition as well as field condition with the help of graph papers at different intervals of time as per the experimental schedule and expressed in $\mathrm{cm}^{2}$.

\section{Leaf area index (L.A.I)}

The Leaf area index was calculated at different growth period for the control and treated sets of both pot-cultured and field plants as per the formulae given below.

$$
\text { L.A.I }=\frac{\text { Total area of the leaves }}{\text { Total area of the land }} \times 100
$$

\section{Statistical analysis}

The data so collected were subjected to statistical analysis for calculation of standard Error of Mean (S.E.M.) and presented in tables only but not in figures to avoid clumsiness.

\section{Results and Discussion}

The vegetative growth parameters such as (a) development of number of green leaves/ plant, (b) height of the plant, (c) total leaf area / plant and (d) leaf area index (LAI) of green gram influenced by test weed in pot culture method as well as field experiments are described below.

\section{Pot culture results}

In this method, different concentrations of whole-plant, leaves and fruits dust of Xanthium were applied into the soil of the pots and their influence on above mentioned vegetative growth parameters of green gram plants are described below.

\section{Development of number of green leaves /plant}

All the concentration of dust considerably checked the production of total number green leaf-lets per plant at different 
developmental stages compared with control plants. i.e., from $4^{\text {th }}$ WAS to flowering compared with control plants. Maximum number of leaf-lets recorded in plants of control set at flowering stage was $14.7 \pm$ 0.21 while it was only $7.6 \pm 0.4$ in plants influenced by $15 \%$ concentrations of wholeplant dust in the soil of pot. Other concentrations exhibited intermediate values (Table-1). A positive correlation was observed between development of number of leaf-lets per plant with advancement of plant age and negative correlations between production of number of leaf-lets per plant and increase of dust concentration of test weed in the soil of pot.

\section{Height of plant}

The height of the test crop plants also exhibited more or less similar trend of correlations with increase of dust concentrations in the soil of pots and advancement of plant age.

\section{Total leaf area / plant}

As the development of total number of green leaf-lets per plant and height of the plants increased with increase of plant age, the total leaf area per plant exhibited more or less similar trends as were noticed in case of the above two parameters. Maximum leaf area of $220.5 \pm 1.0 \mathrm{~cm}^{2}$ was recorded in plants of control set at the time of flowering whereas during the same period of growth it was only $114.0 \pm 1.8 \mathrm{~cm}^{2}$ in plants affected by $15 \%$ concentration of dust. Other concentrations of dust exhibited intermediate values during the period of observation (Table-1).

\section{Leaf area index (L.A.I.)}

The L.A.I is considered as one of the important vegetative growth parameters for its direct involving on metabolic efficiency and yield of concerned crop. In present investigations, it was noticed that all concentrations of test weed-dust considerably reduced the leaf area index / pot. Maximum L.A.I. calculated for plants of control set, at flowering stage was 493.92 whereas it was 255.35 for plants influenced by $15 \%$ concentration of dust in the pot. Data of intermediate values were calculated for plants grown in other concentrations during the period of observation (Table-1). The correlation of L.A.I. with increase of dust concentration and plant age exhibited more or less similar trends as were found in aforesaid three vegetative growth parameters.

The different concentration of leaves-dust and fruits-dust of test weed were considerably reduced all vegetative growth parameters stated above. Like whole-plant dust of test weed, increase of leaves-dust and fruits-dust concentrations exhibited negative correlations with development of number of green leaf-lets/ plant (a), height of the plant (b), total leaf area / plant (c) and leaf area index (LAI)/pot (d) (Fig.-1 and 2). Among the three types of dusts, whole-plant dusts were found to be more toxic than other two types of dusts administered.

\section{Field study results}

The results on changes in vegetative growth parameters of test crop plants influenced by different population of test Xanthium weed conducted in field conditions are described below.

\section{Development of number of green leaf-lets / plant}

From Table-4 it was marked that the production of number of green leaflets/plant was considerably reduced by 
influence of Xanthium weed population in the experimental fields. Plants of control set had maximum number of leaf-lets (15.5 \pm 0.08) per plant at the time of flowering whereas the plants of the plot having 1:3 ratio of crop plant (C.P.): Xanthium plant (X.P.) had only $8.5 \pm 0.7$ leaf-lets/plant at the time of flowering. Plants of other plots having C.P. and X.P. ratio of 3:1 and 1:1 had $15.1 \pm 0.05$ and $13.6 \pm 0.09$ leaf-lets / plant at the time of flowering. Data of intermediate values were recorded for plants of test plots and other plots influenced by Xanthium weed population during the course of observation. The production of leaflets/plant exhibited positive correlation with advancement of plant age and negative correlations with increase in the weed population in respective plots.

\section{Height of the plant}

Higher population of Xanthium weed plant in the experimental plots considerably checked the height of the test crop plants. In control plot, without any test weed plants, the crop plants attained maximum height of $18.5 \pm 0.01 \mathrm{~cm}$ per plant at the time of flowering whereas crop plants of the plot with C.P. and X.P. ratio of 25:75 attained an average height $8.0 \pm 0.08 \mathrm{~cm}$ only. Data of intermediate values were recorded in plants of other plots at different growth period (Table-4). Like production of leaf-lets/plant, height of the test crop plants also exhibited positive correlation with advancement of plant age and negative correlations with increase of test weed population in the field.

\section{Total leaf Area/Plant}

Higher population of test weed plants considerably checked the production of number of leaf-lets/plant as a result the total area per plant reduced significantly compared with plants of control plot.
Maximum height of $232.5 \pm 3.2 \mathrm{~cm}^{2}$ were recorded in plants of control set at the time of flowering while it reduced to $127.5 \pm 1.2$ $\mathrm{cm}^{2}$ in plants of the plot having C.P. and X.P. ratio of 25:75 (Table-4). This is clear testimony of adverse effect of Xanthium weed on growth of test crop. The total leaf area/plot also exhibited negative correlations with increase of test weed population in experimental plot and positive correlation with advancement of plant age.

\section{Leaf Area Index (L.A.I.)}

The leaf area index/plot drastically reduced due to presence of test weed plants in plots. It was observed that the L.A.I. at the time of flowering reduced from 1.02 (control plot) to 0.39 (plot having C.P. and X.P. ratio of 25:75). Intermediate L.A.I. values were calculated for plants of other plots at different developmental stages of crop plant (Table-4). The L.A.I. per plot exhibited positive correlation with advancement of plant age and negative correlations with increase in the weed population in experimental plots during the period of observation.

Vegetative growth of any crop plant is considered as one of the important stage during its life time. At this stage the plants become self sufficient to carry out their metabolic activities as a result the surplus metabolites, after being utilized for its own growth and development, are translocated to the sink where those are stored in various forms and types such as carbohydrates or starch, protein, oil, alkaloids, steroids etc. Basing on the results obtained during the present investigation on the impact of test weed, in form of dust in pot culture method and population growth in field condition, on various vegetative growth parameters of green gram is described below. 


\section{Development of No. of leaflets/plant}

Development of number of green leaves per plant is a type of architecture of plants which directly or indirectly have bearing on yield. Any alterations in production of leaves per plant by different internal as well as external environmental factor cause imbalance between source and sink, hence Vergara et al.,(1966) suggested that the studies of production of leaves and plant height is of prime importance while working on the crop plants.

All concentrations of various types dust of considerably reduced the production of number of leaflets per plant in test cultivars compared with their respective controls. So, these reduced-results might be due to translocation of active ingradients of allelochemicals which are hypoglycaemic, antifungal and cytotoxic (Shong et al., 1962) present in the dust that might have translocated from soil to leaves during seedling growth. Further, the higher concentrations of dust might have controlled or arrested various metabolic processes leaves and caused lesser photosynthates and thus decreased the rate in assimilation of growth-regulators which might have checked the formation of green leaves on test crop plants. Jaykumar et al., (1990) reported that the phenolic acids present in Eucalyptus globulus reduced leaf area, total chlorophyll and plant height in ground nut and corn. Hence, it is expected that such type of phenolic compound, steroids and other phytotoxic compounds, present in various types of dust of test weed might have arrested or checked the synthesis of growth regulators responsible for morphogenesis and production of leaves on test legumes plants. It is further suspected that higher amount of the phytotoxic-active ingredients of various natures released from dust to the soil might have moved along with assimilates which caused reduction in production of leaf-lets/plant.

\section{Height of the plants}

Generally height of the any plants increases due to elongation of leaf sheath (monocarpic plants) and/or internodes in polycarpic plants those are regulated by growth substances like gibberllins and auxins. Khan and Padhy (1988) reported the existence of positive correlation between flowering and shoot elongation in rice. Clenad (1964) suggested that $\mathrm{GA}_{3}$ play important role on elongation of grass leaves. Jones and Philips, (1966) suggested that in many plants high level of $\mathrm{GA}_{3}$ occurs in the apices of stems, and roots, young leaves and embryos endodermis of developing seeds. The movement of $\mathrm{GA}_{3}$ is generally carried out from leaves to the site of action along with other metabolites and act according to the need of the plants. Any alteration in the process of translocation, accumulation and action, results and reflects on growth and development of new leaves on shoot apex or inhabitation of other morphogenesis and/or ontogenic processes. It may also be possible that the phototoxic chemicals entered into the plant system might have checked the synthesis of growth-regulators by preventing synthesis of protein, nucleic acids and other metabolites which are directly or indirectly responsible for synthesis of phytogrowthrelating substances that actively take part in ontogenesis.

In the present investigation the heights of the test crop plants were reduced by the application of dustof different parts of thr test weed in pot-culture experiment and thick population of weed plant in field condition. This inhibitory effect on plant height might be due to checking or inhibiting biosynthesis and translocation of gibberellins which are responsible for cell 
elongation and height. Chakraverty (1983) reported that hadacidine, an active phytotoxic compound present in many weeds, acts both by depressing the biosynthesis of cytokinin and gibberlin in Phaseolus auerous $L c v$. NP. 23 as a result it disrupts normal elongation mechanisms. Key and Ingate (1964), Mosuda (1966), Chakraverty and Raghabhan (1973) suggested that auxins may check the plant height by depressing genes and inducing the synthesis of mRNA and new enzymes which ultimately allow the cell expansion and internal elongation. Thus from the above point of view it might be quite logical to interpret that phytotoxins released from different types of dust of test weed might have induced inhibition of plant growth by preventing the synthesis, translocation, accumulation and activation of gibberellins there by the height of the legume plant significantly decreased.

The present finding corroborate with finding of Jaykumar et al.,(1990) in groun nut and corn, Gantayet (2007) in some legumes influenced by Eucalyptus globalus, Igboanugo (1988) in capsicum influenced by Eucalyptus cetrodora and Basu et al., (1987) in barley influenced by Eucalyptus tereticornis. Among the two types of observation, dust application comparatively checked the plant height more than the weed-plant population in the field condition which indicates that the dust might have released higher quantity of phytotoxins due to decomposition of plant parts compared to root exudates and leaf decomposition of test weed in field condition.

\section{Total leaf area}

The production of number of leaves per plant relates to its photosynthetic and metabolic efficiencies which are directly or indirectly associated with the yield potentiality of concerned crop. Increase in leaf area surface due to production of more leaves has direct relationship with sink. Increase or decrease of leaf area per plant of any crop plants is controlled by various internal and external environmental factors. In present investigation, it is noticed that all concentrations of different types of dust of test weed considerably checked the increase of leaf area of plant in compared with their respective control plants in pot culture experiment. It suggests the negative effect on increase of leaf area per plant might be due to absorbance and translocation of active ingredients of allelochemicals present in soil, released from dust, to leaves during their growth period. Since the decrease in leaf area of test legume plant was directly proportional to increase of concentrations of dusts, it is expected that phenolic compounds released from test weed plants dust might have checked the increase of leaf area by preventing synthesis of protein, nucleic acid and other metabolites which are directly or indirectly responsible for synthesis of growth-regulators. Similar findings have been reported by Jay Kumar et al., (1990), Sahu (2000) and Gantayat (2007) on reduction of leaf area by influence of allelochemicals of other plants in many crop plants.

\section{Leaf area index}

Agronomic point of view, the total leaf area relationship with soil area is considered as one of the most important growth parameter of any crop plant as it has direct relationship with productivity of concerned crop. In present investigation, it was observed that all the concentrations of different types of dust of test-weed significantly lowered the L.A.I. in treated plants compared to their respective control plants. This decreased of L.A.I. might be due to development of lesser number of leaf-lets per unit area of lands where it grows. 
Table.1 Effect of different concentrations of whole-plant-dust of Xanthium indicum on vegetative growth parameters of green gram plants (Each value is mean of 5 replicates \pm S.E.M.)

\begin{tabular}{|c|c|c|c|c|c|}
\hline $\begin{array}{c}\text { Dust } \\
\text { concentration } \\
(\%) \\
\end{array}$ & $\begin{array}{l}\text { Plants age at the } \\
\text { time of recording } \\
\text { (Days) }\end{array}$ & $\begin{array}{c}\text { Total number } \\
\text { of green } \\
\text { leaflets/plant }\end{array}$ & $\begin{array}{c}\text { Height of the } \\
\text { plant }(\mathrm{cm})\end{array}$ & $\begin{array}{c}\text { Total leaf } \\
\text { area/plant } \\
\left(\mathrm{cm}^{2}\right)\end{array}$ & $\begin{array}{c}\text { Leaf area index } \\
\text { per pot }\end{array}$ \\
\hline \multirow[t]{4}{*}{ Control } & 21 & $7.9 \pm 0.15$ & $17.2 \pm 0.22$ & $89.5 \pm 0.7$ & 188.48 \\
\hline & 28 & $10.9 \pm 0.19$ & $19.1 \pm 0.26$ & $119.9 \pm 1.6$ & 268.57 \\
\hline & 35 & $14.0 \pm 0.26$ & $25.9 \pm 0.29$ & $175.0 \pm 2.1$ & 392.00 \\
\hline & $\mathrm{F}$ & $14.7 \pm 0.21$ & $28.4 \pm 0.20$ & $220.5 \pm 1.4$ & 493.92 \\
\hline \multirow[t]{4}{*}{5} & 21 & $5.7 \pm 0.13$ & $15.4 \pm 0.14$ & $62.07 \pm 1.4$ & 140.44 \\
\hline & 28 & $9.3 \pm 0.17$ & $17.3 \pm 0.12$ & $102.03 \pm 1.2$ & 229.15 \\
\hline & 35 & $11.2 \pm 0.15$ & $22.4 \pm 0.10$ & $123.02 \pm 2.1$ & 275.96 \\
\hline & $\mathrm{F}$ & $12.3 \pm 0.11$ & $25.5 \pm 0.11$ & $135.03 \pm 1.4$ & 303.07 \\
\hline \multirow[t]{4}{*}{10} & 21 & $4.7 \pm 0.17$ & $12.9 \pm 0.11$ & $58.75 \pm 2.1$ & 133.60 \\
\hline & 28 & $7.3 \pm 0.16$ & $14.7 \pm 0.13$ & $91.25 \pm 0.7$ & 204.41 \\
\hline & 35 & $8.8 \pm 0.14$ & $16.4 \pm 0.22$ & $110.00 \pm 0.8$ & 246.46 \\
\hline & $\mathrm{F}$ & $9.2 \pm 0.5$ & $18.4 \pm 0.20$ & $115.00 \pm 1.2$ & 257.60 \\
\hline \multirow[t]{4}{*}{15} & 21 & $3.9 \pm 0.8$ & $10.9 \pm 0.13$ & $45.05 \pm 0.9$ & 121.04 \\
\hline & 28 & $5.9 \pm 0.10$ & $13.7 \pm 0.17$ & $88.51 \pm 0.5$ & 198.24 \\
\hline & 35 & $7.2 \pm 0.13$ & $15.4 \pm 0.20$ & $108.08 \pm 0.9$ & 241.42 \\
\hline & $\mathrm{F}$ & $7.6 \pm 0.14$ & $17.9 \pm 0.25$ & $114.25 \pm 1.8$ & 255.36 \\
\hline \multirow[t]{4}{*}{20} & 21 & $*$ & $*$ & $*$ & $*$ \\
\hline & 28 & $*$ & $*$ & $*$ & $*$ \\
\hline & 35 & $*$ & $*$ & $*$ & $*$ \\
\hline & $\mathrm{F}$ & * & * & * & $*$ \\
\hline
\end{tabular}

Table.2 Effect of different concentrations of dust of Xanthium indicum leaves on vegetative growth parameters of green gram plants (Each value is mean of 5 replicates \pm S.E.M.)

\begin{tabular}{|c|c|c|c|c|c|}
\hline $\begin{array}{c}\text { Dust } \\
\text { concentration } \\
(\%)\end{array}$ & $\begin{array}{l}\text { Plants age at the } \\
\text { time of recording } \\
\text { (Days) }\end{array}$ & $\begin{array}{c}\text { Total number of } \\
\text { green } \\
\text { leaflets/plant }\end{array}$ & $\begin{array}{l}\text { Height of the } \\
\text { plant }(\mathrm{cm})\end{array}$ & $\begin{array}{c}\text { Total leaf } \\
\text { area/plant } \\
\left(\mathrm{cm}^{2}\right)\end{array}$ & $\begin{array}{c}\text { Leaf area index } \\
\text { per pot }\end{array}$ \\
\hline \multirow[t]{4}{*}{ Control } & 21 & $7.9 \pm 0.15$ & $17.2 \pm 0.22$ & $89.5 \pm 0.7$ & 188.48 \\
\hline & 28 & $10.9 \pm 0.19$ & $19.1 \pm 0.26$ & $119.9 \pm 1.6$ & 268.57 \\
\hline & 35 & $14.0 \pm 0.26$ & $25.9 \pm 0.29$ & $175.0 \pm 2.1$ & 392.00 \\
\hline & $\mathrm{F}$ & $14.7 \pm 0.21$ & $28.4 \pm 0.20$ & $220.5 \pm 1.4$ & 493.92 \\
\hline \multirow[t]{4}{*}{5} & 21 & $6.2 \pm 0.11$ & $15.9 \pm 0.14$ & $68.02 \pm 1.3$ & 152.76 \\
\hline & 28 & $9.8 \pm 0.13$ & $17.8 \pm 0.12$ & $107.08 \pm 1.8$ & 241.47 \\
\hline & 35 & $11.7 \pm 0.15$ & $22.9 \pm 0.10$ & $128.07 \pm 2.4$ & 288.28 \\
\hline & $\mathrm{F}$ & $12.8 \pm 0.16$ & $26.0 \pm 0.12$ & $140.08 \pm 2.6$ & 315.39 \\
\hline \multirow[t]{4}{*}{10} & 21 & $5.2 \pm 0.09$ & $13.4 \pm 0.12$ & $65.00 \pm 2.2$ & 145.60 \\
\hline & 28 & $7.8 \pm 0.16$ & $15.2 \pm 0.14$ & $97.05 \pm 0.8$ & 214.61 \\
\hline & 35 & $9.3 \pm 0.17$ & $18.9 \pm 0.21$ & $116.25 \pm 1.0$ & 260.40 \\
\hline & $\mathrm{F}$ & $9.7 \pm 0.15$ & $21.4 \pm 0.23$ & $131.25 \pm 1.7$ & 281.60 \\
\hline \multirow[t]{4}{*}{15} & 21 & $4.4 \pm 0.09$ & $10.4 \pm 0.14$ & $60.00 \pm 1.1$ & 140.84 \\
\hline & 28 & $6.4 \pm 0.11$ & $12.2 \pm 0.18$ & $90.40 \pm 0.7$ & 200.04 \\
\hline & 35 & $7.7 \pm 0.14$ & $15.9 \pm 0.21$ & $110.50 \pm 2.1$ & 238.72 \\
\hline & $\mathrm{F}$ & $8.1 \pm 0.13$ & $18.4 \pm 0.26$ & $121.25 \pm 2.1$ & 252.16 \\
\hline \multirow[t]{4}{*}{20} & 21 & $*$ & $*$ & $*$ & $*$ \\
\hline & 28 & * & $*$ & $*$ & $*$ \\
\hline & 35 & $*$ & $*$ & $*$ & $*$ \\
\hline & $\mathrm{F}$ & $*$ & $*$ & * & $*$ \\
\hline
\end{tabular}


Table.3 Effect of different concentrations of dust of Xanthium indicum fruit on vegetative growth parameters of green gram plants. (Each value is mean of 5 replicates \pm S.E.M.)

\begin{tabular}{|c|c|c|c|c|c|}
\hline $\begin{array}{c}\text { Dust } \\
\text { concentration } \\
(\%)\end{array}$ & $\begin{array}{l}\text { Plants age at } \\
\text { the time of } \\
\text { recording } \\
\text { (Days) }\end{array}$ & $\begin{array}{c}\text { Total number } \\
\text { of green } \\
\text { leaflets/plant }\end{array}$ & $\begin{array}{c}\text { Height of the } \\
\text { plant }(\mathrm{cm})\end{array}$ & $\begin{array}{c}\text { Total leaf } \\
\text { area/plant } \\
\left(\mathrm{cm}^{2}\right)\end{array}$ & $\begin{array}{c}\text { Leaf area index } \\
\text { per pot }\end{array}$ \\
\hline \multirow[t]{4}{*}{ Control } & 21 & $7.9 \pm 0.15$ & $17.2 \pm 0.22$ & $89.5 \pm 0.7$ & 188.48 \\
\hline & 28 & $10.9 \pm 0.19$ & $19.1 \pm 0.26$ & $119.9 \pm 1.6$ & 268.57 \\
\hline & 35 & $14.0 \pm 0.26$ & $25.9 \pm 0.29$ & $175.0 \pm 2.1$ & 392.00 \\
\hline & $\mathrm{F}$ & $14.7 \pm 0.21$ & $28.4 \pm 0.20$ & $220.5 \pm 1.4$ & 493.92 \\
\hline \multirow[t]{4}{*}{5} & 21 & $6.7 \pm 0.13$ & $16.4 \pm 0.15$ & $73.70 \pm 1.4$ & 165.08 \\
\hline & 28 & $10.3 \pm 0.17$ & $18.3 \pm 0.13$ & $113.30 \pm 1.9$ & 253.73 \\
\hline & 35 & $12.5 \pm 0.14$ & $23.4 \pm 0.11$ & $137.50 \pm 2.5$ & 308.00 \\
\hline & $\mathrm{F}$ & $13.3 \pm 0.15$ & $26.5 \pm 0.12$ & $145.30 \pm 2.7$ & 327.70 \\
\hline \multirow[t]{4}{*}{10} & 21 & $5.7 \pm 0.14$ & $13.9 \pm 0.11$ & $71.25 \pm 0.7$ & 159.60 \\
\hline & 28 & $8.3 \pm 0.16$ & $15.7 \pm 0.13$ & $103.75 \pm 1.3$ & 232.40 \\
\hline & 35 & $9.8 \pm 0.17$ & $19.4 \pm 0.16$ & $122.50 \pm 1.7$ & 274.40 \\
\hline & $\mathrm{F}$ & $10.2 \pm 0.15$ & $21.9 \pm 0.17$ & $127.50 \pm 1.5$ & 285.60 \\
\hline \multirow[t]{4}{*}{15} & 21 & $4.9 \pm 0.09$ & $10.8 \pm 0.14$ & $63.50 \pm 1.2$ & 140.64 \\
\hline & 28 & $6.9 \pm 0.11$ & $13.9 \pm 0.18$ & $100.50 \pm 0.8$ & 200.64 \\
\hline & 35 & $8.2 \pm 0.14$ & $16.7 \pm 0.21$ & $118.00 \pm 1.5$ & 245.52 \\
\hline & $\mathrm{F}$ & $8.6 \pm 0.13$ & $19.3 \pm 0.26$ & $122.00 \pm 2.2$ & 268.96 \\
\hline \multirow[t]{4}{*}{20} & 21 & $*$ & $*$ & $*$ & $*$ \\
\hline & 28 & $*$ & $*$ & $*$ & $*$ \\
\hline & 35 & $*$ & $*$ & $*$ & $*$ \\
\hline & $\mathrm{F}$ & * & $*$ & $*$ & $*$ \\
\hline
\end{tabular}

Table.4 Changes in vegetative growth parameters of Green gram plant influence of Xanthium indicum plant density in field conditions. (Each value is mean of 5 replicates \pm S.E.M.)

\begin{tabular}{|c|c|c|c|c|c|}
\hline $\begin{array}{c}\text { Ratio of crop } \\
\text { plant (C.P.) \& } \\
\text { Xanthium plant } \\
\text { per plot } \\
\text { (C.P. : X.P.) }\end{array}$ & $\begin{array}{l}\text { Plants age at } \\
\text { the time of } \\
\text { recording } \\
\text { (Days) }\end{array}$ & $\begin{array}{c}\text { Total number } \\
\text { of green } \\
\text { leaflets/plant }\end{array}$ & $\begin{array}{l}\text { Height of the } \\
\text { plant }(\mathrm{cm})\end{array}$ & $\begin{array}{c}\text { Total leaf } \\
\text { area/plant } \\
\left(\mathrm{cm}^{2}\right)\end{array}$ & $\begin{array}{l}\text { Leaf area index } \\
\text { per pot }\end{array}$ \\
\hline \multirow[t]{4}{*}{$100: 00$} & 21 & $7.0 \pm 0.07$ & $6.5 \pm 0.10$ & $35.2 \pm 1.3$ & 0.35 \\
\hline & 28 & $9.0 \pm 0.05$ & $9.2 \pm 0.11$ & $99.3 \pm 1.5$ & 0.99 \\
\hline & 35 & $11.5 \pm 0.06$ & $10.7 \pm 0.13$ & $143.7 \pm 2.5$ & 1.43 \\
\hline & $\mathrm{F}$ & $15.5 \pm 0.08$ & $18.5 \pm 0.17$ & $232.5 \pm 3.2$ & 2.32 \\
\hline \multirow[t]{4}{*}{$75: 25$} & 21 & $6.5 \pm 0.05$ & $5.3 \pm 0.09$ & $32.2 \pm 1.2$ & 0.24 \\
\hline & 28 & $8.2 \pm 0.07$ & $6.7 \pm 0.13$ & $90.3 \pm 1.6$ & 0.67 \\
\hline & 35 & $11.0 \pm 0.08$ & $8.1 \pm 0.14$ & $137.7 \pm 1.9$ & 1.03 \\
\hline & $\mathrm{F}$ & $15.1 \pm 0.05$ & $14.2 \pm 0.18$ & $226.5 \pm 1.5$ & 1.69 \\
\hline \multirow[t]{4}{*}{$50: 50$} & 21 & $5.8 \pm 0.07$ & $4.2 \pm 0.09$ & $29.4 \pm 1.8$ & 0.14 \\
\hline & 28 & $7.9 \pm 0.09$ & $5.8 \pm 0.10$ & $86.9 \pm 1.1$ & 0.43 \\
\hline & 35 & $10.5 \pm 0.11$ & $6.2 \pm 0.11$ & $131.2 \pm 1.5$ & 0.65 \\
\hline & $\mathrm{F}$ & $13.6 \pm 0.09$ & $9.2 \pm 0.14$ & $204.4 \pm 1.7$ & 1.02 \\
\hline \multirow[t]{4}{*}{$25: 75$} & 21 & $5.0 \pm 0.05$ & $3.4 \pm 0.07$ & $25.3 \pm 1.7$ & 0.06 \\
\hline & 28 & $8.8 \pm 0.07$ & $4.8 \pm 0.09$ & $63.8 \pm 2.3$ & 0.15 \\
\hline & 35 & $6.9 \pm 0.09$ & $5.2 \pm 0.08$ & $86.2 \pm 1.8$ & 0.21 \\
\hline & $\mathrm{F}$ & $8.5 \pm 0.07$ & $8.0 \pm 0.08$ & $127.5 \pm 13.2$ & 0.31 \\
\hline
\end{tabular}


As the development of leaf-lets per plant was considerably reduced and thus the L.A.I. also reduced proportionately as the land area in which the plant grows is remaining constant. In case of field condition, higher the number of weeds per plot, lower was the L.A.I. value, which indicates the interference of weed density per plot. Due to inadequate literature related to L.A.I. on this aspect are available, no definite or specific interpretation and conclusions can be drawn. This needs indepth studies at molecular and submolecular levels on impact of specific allelochemics on specific growth parameter.

\section{Acknowledgement}

The authors wish to express sincere thanks to the Principal, Aska Science College, Aska for his encouragement and providing necessary facilities. The authors are also grateful to Prof. Bhaskar Padhy, (Retd.), Department of Botany, Berhampur University, Berhampur, Odisha for his constant support, encouragement and revision.

\section{References}

Ahmed, R., Uddin, M. B. and Hossain, M.K. 2004. Allelopathic effect of leaf extracts of Eucalyptus camaldulensis Dehn. on agricultural crops. Bangladesh J. Bot., 33(2): 79-84.

Ahmed, R., Uddin, M.B. Khan, M.A.S., Mukul, S.A. and Hossain, M.K. 2007. Allelopathic effect of Lantana camara on germination and growth behavior of some agricultural crops in Bangladesh. J. Forestry Res., 18(4): 301-304.

Basu, P.K., Kapoor, K.S., Nanth, S., Banerjee, S.K., 1987. Allelopathic influence: An assessment on the response of agricultural crops growing near Eucalyptus tereticornis. Indian J. of Forestry, 10(4): 267-271.

Blum, U., Shafer, S.R. and Lehman, M.E., 1999. Evidence for inhibitory allelopathic interactions; involving phenolic acids in field soils. Cri. Rev. in plant Sci., 18: 673-693.

Chakravarty, R.K. 1983. Mode of action of hadacidin in plants. Acta. Bot. Ind., 11: 53-56.

Chakravarty, S.C. and Raghavaran, N.V., 1997. Effect of Gibberllic acid on the maturity and internode elongation of Pea plant. Indian J. Plant Physol., 81(XVI 1\&2): 5-6.

Chon, S.U., Choi, S.K., Jung, H.G., Pyo, B.S. and Kims, M. 2002. Effects of Alfalfa leaf extract and phenolics allelochemicals on early seedling growth of banyard grass. Crop Protection, 5: 107-138.

Chon, S.U., Jang, H.G., Kim., Y.M., Boo, H.O. and Kim, Y.J. 2005. Allelopathic potential in lettuce (Lectuca sativa L.) plant. Scientia Horticulturae, 106: 309- 317.

Cleland, R. 1964. The role of endogenous auxin in the elongation of Avena leaf sections. Physiol. Plant, 17: 126-135.

Dash, N., Rath, I. and Adhikary, S.P. 2013. Allelopathic effects of Acacia auriculaeformis on some enzymatic activity in Ragi (Elusine caracona Gaertn.). Eco. Env. \& Cons., 19(3): 167-172.

Day, M.D., Wiley, C.J., Playford, J. and Zalucki, M.P. 2003. Lantana: current management status and future prospects. (Australian Centre for International Agricultural Research: Canberra).

Duke, S.O., Dayan, E.F., Romangi, J.G. and Rimando, A.M. 2000. Natural products as sources of herbicides. Current status and future trend. Weed Res., 10: 99111.

Dunenli, A., Uygur, F.N., Turkmen, N., 
Uygur, S. and Boz, O. 1993. The features of the important weed species in the Mediterrenean Region Turkey. Turkish I. Herbology Congr., 3-5 Feb.1993, Adana-turkey: 77-86.

Gantayat, P.K. 2007. Studies on Allelopathic effects of Eucalyptus on some legume crops. Ph. D. Thesis, Berhampur University, Odissa, India.

Igboanugo, A.B.I. 1988b. Preliminary studies on phytotoxic growth and yield inhibitions of Capsicum annum by Eucalyptus citriodora. Biol. Agric. and Hort., 54: 339-345. Inderjit, I. 1996. Plant phenolics in allelopathy. Botanical Review, 62: 186-202.

Jayakumar, M., Eyini, M. and Pannirselvam, S. 1990. Allelopathic effect of Eucalyptus globulus Labill. in groundnut and corn. Comp. Physiol. Eco., 15 (3):109-113

Jones, R.L. and Philips, I.D.J. 1966. Organs of gibberellin synthesis in light-grown sunflower plants. Plant Physiol., 41: 1381-1386.

Kadioglu, I. 1997. Studies on germination biology and germination depth of some of the weed species found in cotton fields in Mediterrenean Region Turkey. Turkish II. Herbology Congr., 1-4 Sept.1997, Izmir-turkey: 205-218.

Kaletha, M.S., Bhatt, B.P. and Todaria, N.P. 1996. Tree crop interactions in traditional agroforestry systems of Garhwal Himalaya. Phytotoxic effect of farm trees on food crops. Allelopathy J., 3(2): 247-250.

Key, J.L. and Ingle, J. 1964. Requirement for the synthesis of DNA like RNA for growth of excised plant tissues. Proc. Nat. Acad. USA., 528: 1382-1388.

Khan, P.A. and Padhy, B. 1988. Aging effect on relation between the photoperiodic dosage and internal elongation of rice. J. Berhampur University, 9: 96-100.

Kumar, M., Lakiang, J. J. and Gopichand, B., 2006. Phytotoxic effect of agroforestry tree crops on germination and radicle growth of some food crops of Mizoram. Lyonia. J. Ecol. Appli., 1(2): 83-89.

Li, Z.H., Wang, Q., Ruan, X., Pan, C.D. and Jiang, D.A. 2010. Phenolics and plant allelopathy. Mol., 15: 8933-8952.

Mosuda, T. 1966. Axin induced growth of tuber tissue of jerusalem artichokell. The relation to protein and nucleic acid metabolism. Plant Physiol., 7: 75-91.

Padhy, B., Mishra, P. and Gantayat, P.K. 2002. The Allium test, An alternative bioassay in allelopathic studies: Impact of aqueous phyllode-litter leachate of Acacia auriculaeformis. Indian J. Environ. Eco-Planning, 6: 99-104.

Putman, A.R. and DeFrank, J. 1983. Use of phytotoxic plant residues for selective weed control. Crop Prot., 2: 173-181.

Saffari, M. and Torabi-Sirchi, M.H. 2011. Allelopathic Effects of Straw Extract from Two Native Iranian Wheat Varieties on the Growth of Two Corn Varieties (Single Cross 647, 704). American-Eurasian J. Agri. Environ. Sci., 10(2): 133-139.

Sahu, U. 2000. Impact of certain Biopesticides on some crop plants. Ph. D. Thesis, Berhampur university, Berhampur, Odisha, India.

Shajie, E. and Saffari, M. 2007. Allelopathic effects of cocklebar (Xanthium strumarium L.) on germination and seedling growth of some crops. Allelopathy J., 19: 501-506.

Shong, Z.Y. et al., 1962. Medicinal plant in Republic Korea Xanthium stumarium L. . Yaoxue Xuebao, 9: 678.

Siddiqui, S., Bhardwaj, S., Khan, S. Saeed and Meghvanshi, M. Kumar, 2009. 
Allelopathic Effect of Different Concentration of Water Extract of Prosopsis Juliflora Leaf on Seed Germination and Radicle Length of Wheat (Triticum aestivum Var-Lok-1). American-Eurasian J. Scientific Res., 4(2): 81-84.

Tanveer, A., M. Tahir, M.A. Nadeem, M. Youniss, A. Aziz and M. Yaseen, 2008. Allelopathic effects of Xanthium strumarium L. on seed germination and seedling growth of crops. Allelopathy J., 21(2): 317-328.
Uddin, M.B., Ahmed, R., Mukul, S.A. and Hossain, M.K. 2007. Inhibitory effects of Albizia lebbeck (L.) Benth. Leaf extracts on germination and growth behavior of some popular agricultural crops. J. Forestry Res., 18(2): 128132.

Vergara, B.S. 1966. Crop reponse to light variations. Relationship between growth duration and grain yield of rice plants. Soil Sci. and Plant Nutr., 12: $137-153$.

\section{How to cite this article:}

Adhikary, S.P., and Sabat, S.N. 2016. Impact of Cocklebur (Xanthium indicum) Allelochemicals on Vegetative Growth Parameters of Green Gram (Phaseolus radiatus L.). Int.J.Curr.Microbiol.App.Sci. 5(11): 552-564. doi: http://dx.doi.org/10.20546/ijcmas.2016.511.066 